\title{
ANALISIS QARDH DALAM PEMBIAYAAN RAHN DI LEMBAGA KEUANGAN SYARIAH, INDONESIA (STUDI KASUS PINJAMAN USAHA)
}

\author{
Siska Hana Pertiwi ${ }^{1}$, Iza Hanifuddin ${ }^{2}$ \\ ${ }^{1,2}$ Institut Agama Islam Negeri Ponorogo, Indonesia \\ Email: siskahana07@gmail.com ${ }^{1}$, izahanifuddin@iainponorogo.ac.id ${ }^{2}$
}

\begin{abstract}
This study aims to look at the role of LKS in providing business loans, as well as to dissect the conditions and systematics of the Qardh contract in financing Rahn. The method used is descriptive analysis with literature studies, and uses secondary data sourced from theses, journals, and websites of related institutions. Qardh and Rahn run within the framework of sharia, which is based on the Qur'an and Hadith, as well as the Ijtihad of scholars. Qardh and Rahn have operational provisions in the DSN-MUI Fatwa, as well as Laws and Regulations Number 21 of 2008 concerning Islamic Banking. Qardh and Rahn, each of which has pillars and conditions that must be fulfilled in the contract and becomes a determinant of whether the contract is valid or not. Both financing must also go through a coherent transaction flow to reach a valid contract. The transfer of loans from conventional systems to sharia is necessary because of the prevalence of fraud and the practice of usury. Islamic Financial Institutions already have institutional legality and the validity of their financing products. Qardh and Rahn are purely loans without compensation, but are profit sharing for Rahn's transactions. Qardh and Rahn share the same goal of supporting community efforts. Qardh is purely a social goal, not consumptive, while Rahn can be productive and consumptive, and LKS earns profit sharing.
\end{abstract}

Keywords: qardh, rahn, akad, financing, islamic financial institutions (LKS)

Abstrak: Penelitian ini bertujuan untuk melihat peran LKS dalam menyediakan pinjaman usaha, serta membedah kondisi dan sistematika akad Qardh dalam pembiayaan Rahn. Metode yang digunakan adalah analisis deskriptif dengan studi literatur, serta menggunakan data sekunder yang bersumber dari skripsi, jurnal, dan website lembaga terkait. Qardh dan Rahn berjalan dalam bingkai syariah, yang berlandaskan Al-Qur'an dan Hadist, serta Ijtihad ulama. Qardh dan Rahn memiliki ketentuan operasional didalam Fatwa DSN-MUI, serta Peraturan Perundang-Undangan Nomor 21 Tahun 2008 Tentang Perbankan Syariah. Qardh dan Rahn, masing-masing memiliki rukun dan syarat yang wajib terpenuhi dalam akad tersebut dan menjadi penentu sah tidaknya akad. Kedua pembiayaan tersebut juga harus melalui alur traksaksi yang runtut untuk mencapai akad yang sah. Pengalihan pinjaman dari sistem konvensional ke syariah diperlukan karena maraknya penipuan dan masih ditemukannya praktik Riba. Lembaga Keuangan Syariah sudah memiliki legalitas lembaga dan keabsahan produk pembiayaannya. Qardh dan Rahn murni pinjaman tanpa imbalan, melainkan bagi hasil bagi transaksi Rahn. Qardh dan Rahn memiliki tujuan yang sama untuk menyokong usaha masyarakat. Qardh murni tujuan sosial bukan konsumtif, sedangkan Rahn bisa produktif dan konsumtif, serta LKS memperoleh bagi hasil.

Kata Kunci : qardh, rahn, akad, pembiayaan, lembaga keuangan syariah (LKS) 


\section{PENDAHULUAN}

Lembaga keuangan berperan penting dalam keberlangsungan kegiatan ekonomi masyarakat, terutama pelaku usaha karena sebagai penyokong modal pelaku usaha kecil dan menengah, serta keberlangsungan hidup masyarakat. Lembaga keuangan yang banyak dikenal masyarakat bersistem konvensional, semakin berkembangnya lembaga keuangan hadir lembaga keuangan bersistem syariah, yang disebut Lembaga Keuangan Syariah (LKS). LKS dengan sistem syariah berlandaskan Al-Qur'an dan Hadist, serta ijtihad Ulama' dirasa mampu bersaing dengan sistem konvensional yang lebih dulu dipergunakan oleh masyarakat, adanya sistem ini membuktikan bahwa prinsip islam didalamnya akan memberikan keamanan dan kemaslahatan bagi masyarakat. Perbedaaan produk pembiayaan LKS dengan konvensional terletak pada sistem bunga, konvensional menggunakan sistem bunga dalam pembiayaannya, sedangkan LKS menggunakan sistem bagi hasil yang tidak akan merugikan nasabah dan berjalan dalam bingkai syari'ah (Ash-Shiddiqy, 2018, hlm. 102-110).

Berdasarkan rujukan Fatwa DSN-MUI No.1 tahun 2004 tentang Bunga, bahwa sistem bunga dari segi definisi dan hukumnya sama dengan Riba, di mana didalam AlQur'an dan Hadist, serta Ijma' Ulama menghukumi bunga sama dengan Riba, yaitu haram (MUI, 2004). Pembiayaan LKS membantu pertumbuhan jumlah pelaku usaha di berbagai daerah dan pengembangan usaha, LKS dirasa lebih aman dalam menjaga hak nasabah, pembiayaan ini membuktikan bahwa nasabah benar-benar dibantu dan tidak ada unsur keuntungan finansial yang dipeoleh LKS, selain dengan jalan bagi hasil. LKS memiliki berbagai macam pembiayaan dalam membantu permodalam pelaku usaha, antara lain: Mudharabah (kerjasama antara bank dengan nasabah dalam bentuk modal dan pengelolaan kerja), Murabahah (jual beli barang dengan keuntungan yang disepakti, bayar ditangguhkan atau lunas), dan Qardh (peminjaman modal yang harus dikembalikan, tanpa imbalan) (Ash-Shiddiqy, 2018, hlm. 102-110). Dalam makalah ini penulis akan mengkaji produk pembiayaan Qardh dan Rahn, akad Qardh dalam praktiknya membantu perekonomian masyarakat baik kelas bawah atau menengah, golongan mereka membutuhkan uluran tangan dalam keberlangsungan hidup (Abdillah, 2021, hlm. 42-51).

Dikategorikan sebagai 'aqd tatawu'i (akad saling bantu membantu), Qardh merupakan bentuk kegiatan sosial dalam membantu saudara kita yang membutuhkan dana untuk kepentingan mendesak dan bukan untuk kepentingan konsumtif semata 
(Nugroho, 2020, hlm. 33-46). Qardh sendiri adalah akad pinjam meminjamkan harta oleh orang yang membutuhkan dan harus dikembalikan sesuai nominal awal, tanpa imbalan dan dikembalikan dengan jangka waktu tertentu sesuai kesepkatan nasabah dengan LKS, bisa dengan mengangsur dan dibayar keseluruhan dari pinjaman (Abdillah, 2021, hlm. 42-51). Dana yang dipergunakan dalam pembiayaan Qardh berdasarkan Fatwa DSN-MUI No: 19/DSN-MUI/IV/2001 tentang Al-Qardh, ada beberapa sumber dana pembiayaan Qardh, antara lain: bagian modal LKS, penyisihan keuntungan LKS, serta lembaga atau perseorangan yang menyalurkan hartanya untuk diinfaqkan kepada LKS (MUI, 2001).

Oleh karena itu, penyaluran dana dengan akad Qardh ini bisa terus dilakukan karena menghimpun dana dari zakat, shadaqah, dan infaq bisa dilakukan kapan saja, tidak terbatas waktu dan ruang, kecuali zakat fitrah (Oktavia, 2020, hlm. 59). Selain memperhatikan Fatwa DSN-MUI No: 19/DSN-MUI/IV/2001 tentang Al-Qardh, mengenai sumber dana pembiayaan Qardh LKS juga mempergunakan pedoman Fatwa DSN-MUI No: 123/DSN-MUI/XI/2018 tentang Penggunaan dana yang tidak boleh diakui sebagai pendapatan bagi lembaga keuangan syariah, lembaga bisnis syariah dan lembaga perekonomian syariah, didalam fatwa tersebut dijelaskan bahwa LKS memiliki dana TDBSP (dana yang tidak boleh diakui sebagai pendapatan), yang harus digunakan dalam kegiatan sosial, salah satu wujudnya pembiayaan Qardh (MUI, 2018). Sehingga garis besar kegiatan Qardh adalah menghimpun dana yang khusus digunakan untuk kepentingan sosial.

Implementasi Qardh bisa ditemukan dalam bentuk pembiayaan LKS lainnya, seperti akad Rahn di mana keduanya sama-sama bentuk akad tatawu'i untuk membantu orang yang membutuhkan dana mendesak. Perbedaan keduanya terletak pada syarat jaminannya, Qardh tidak menggunakan jaminan, sedangkan Rahn menggunakan jaminan. Sama halnya dengan Qardh, Rahn juga menghimpun dana dari masyarakat dan di salurkan kembali dalam wujud pembiayaan(Susilo, 2017, hlm. 131-136). Rahn sendiri ialah perjanjian utang piutang antara penghutang dengan piutang, di mana penghutang menjaminkan harta bendanya sebagai jaminan kepercayaan dan rasa tanggung jawab penghutang kepada piutang atas pinjaman(Febrianasari, 2020, hlm. 139-208). Sebagai lembaga yang dipercaya mampu menjaga keamanan hak masyarakat, LKS harus mampu mengelola risiko keuangan dan risiko lainnya untuk menumbuhkan kepercayaan masyarakat. 
Penghimpunan dana oleh dan untuk masyarakat salah satu bentuk distribusi kekayaan melalui jaminan hak. Hak masyarakat untuk mengembangkan dan memperbaiki kesejahteraan hidupnya, serta hak debitur (LKS) dalam pengamanan hartanya yang dipinjamkan tersebut. Qardh dalam bentuk pembiayaan Rahn akan memberi jaminan dan kepercayaan masyarakat. Jaminan yang ditawarkan dari sisi debitur akan memberikan rasa aman atas pinjamannya karena ada jaminan yang bisa dipertanggungjawabkan atas pinjaman, sedangkan dari sisi kreditur akan memberikan kenyamanan dan rasa tanggung jawab atas pinjaman tersebut. Rahn dalam LKS berbeda dengan gadai konvensional yang menggunakan sistem bunga, sedangkan Rahn menggunakan sistem bagi hasil (Susilo, 2017, hlm. 121-136).

Kondisi kesejahteraan dan ekonomi masyarakat yang dinamis membuat beberapa kalangan kesulitan dalam memenuhi kebutuhan hidup ataupun dalam dunia usaha untuk mengembangkan usahanya, sehingga sekarang ini banyak sekali peminjam kepada kreditur. Namun tidak sedikit kreditur menggunakan tabir pinjaman untuk menipu kreditur dan membawa lari uang pinjaman, oleh karena itu keamanan debitur diwujudkan atas barang agunan. Kreditur juga diberi keamanan untuk memilih tempat gadai (Rahn) yang sudah terdaftar di lembaga terkait dan kredibel. Transaksi gadai sudah lama dilakukan dalam sejarah peradaban manusia, di Indonesia sendiri gadai sudah ada lebih dari seratus tahun, sejak zaman penjajahan pemerintah Belanda (VOC). Namun dahulu masih dengan sistem konvensional dengan bunga. Gadai konvensional dirasa bukan membantu orang yang membutuhkan, justru semakin menyengsarakan mereka karena harus menanggung besaran bunga(Afdhila, 2013, hlm. 1-14). Disamping sisi sejarah konvensional ternyata Rahn (Gadai Syariah) sudah dipraktikkan sejak zaman Rasulullah Saw(Surepno, 2018, hlm. 174-186). Hingga sekarang gadai masih dipergunakan, semakin maraknya lembaga gadai, MUI mengeluarkan Fatwa DSN-MUI No. 25/DSN-MUI/III/2002 tentang Rahn (MUI, 2002).

Diterbitkannya Fatwa tersebut membawa angin segar bagi lembaga gadai syariah di Indinesia, keberadaannya semakin pesat dan minat masyarakat semakin meningkat. Bentuk implementasi Qardh salah satunya adalah Rahn karena sesuai dengan prinsipprinsip syariah, antara lain : Ijarah, Qardhul hasan, Rahn, Mudharabah, Murabahah, dan Ba’i Muqayadah(Afdhila, 2013, hlm. 1-14). Pinjaman Rahn dikembalikan seperti nominal awal peminjaman, tanpa adanya imbalan. Imbalan yang dijanjikan ketika akad di hukumi sama dengan Riba dan secara hukum syara' ialah haram. Menarik 
kebelakang tumbuhnya gadai syariah di Indonesia tidak lepas dari tuntutan idealisme atas keberhasilan lembaga serumpunnya, seperti Bank, Asuransi Syariah, BPR, dan BMT. Penyebab kemunculan gadai syariah karena bank sebagai lembaga utama penyalur dana kala itu tidak mampu memfasilitasi pembiayaan Rahn, sedangkan berdasarkan riset masyarakat sangat membutuhkan pembiayaan Rahn.

Selain ketidak mampuan bank dalam fasiltator Rahn, keberadaan gadai syariah juga kurang diketahui masyarakat sebagai lembaga keuangan mandiri. Berangkat dari persoalan tersebut, maka pada tahun 2003 didirikanlah Pegadaian Syariah (Lubaba, 2020, hlm. 49-58). Penelitian ini dirasa penting, pasalnya masyarakat kurang memahami pembiayaan didalam Lembaga Keuangan Syariah (LKS) dan kurang bisa membedakan antar pembiayaan di LKS, sehingga sering terjadi salah pemahaman dan berakibat pada kurangya daya tarik terhadap LKS. Penelitian dikaitkan dengan akad Qard dan Rahn di LKS karena jika hanya melihat akadnya secara teori mereka memiliki persamaan dan keduanya bisa dikolaborasikan dalam pembiayaan dengan ketentuan, meskipun memiliki kesamaan dan bisa dikolaborasikan, keduanya juga memiliki perbedaan yang harus masyarakat ketauhi dan pahami. Penulis dalam makalah ini akan membedah dua pembiayaan, yaitu Qardh dan Rahn, akan di analisis secara mendalam mengenai topik utama. Apakah pembiayaan Rahn salah satu bentuk akad Qardh?

\section{KAJIAN LITERATUR}

\section{Landasan Normative Qardh dan Rahn (Al-Qur'an, Hadist dan Fiqh Muamalah)}

Ada beberapa hal yang mendasari penelitian ini dengan berlandaskan teori dan pendapat para ahli. Berikut beberapa tiang dari kasus yang diangkat dalam penelitian ini, antara lain:

\section{Qardh}

Qardh secara bahasa dari kata al-qath'u yang bermakna memotong. Dimaknai juga sebagai harta yang dipinjamkan kepada orang yang berhutang. Pada implementasinya Qardh tergolong akad sosial dengan meminjamkan harta kepada orang yang membutuhkan bantuan dana dan pinjaman Qardh tidak dipungut biaya tambahan, peminjam cukup pengembalikan pokok pinjaman. Beberapa ahli figh juga memiliki pandangan mengenai Qardh, antara lain: 
a. Madzhab Syafi'i

Qardh ialah pemindahan hak kepemilikan sementara dari pemilik ke peminjam dan peminjam harus mengembalikan pinjaman tersebut dengan waktu yang disepakati.

b. Madzhab Maliki

Qardh ialah pengembalian dari harta yang dipinjam dengan jumlah seperti yang dipinjam.

c. Madzhab Hambali

Qardh ialah pengembalian harta oleh seseorang yang memperoleh manfaat atas pinjaman tersebut dan dikembalikan sesuai yang dipinjam.

d. Madzhab Hanafi

Menurut Ibnu Abidin, Qardh ialah harta yang dimiliki oleh seseorang yang diberi pinjam kepada orang lain dan yang dipinjami mengembalikan tanpa tambahan atau imbalas atas harta pinjaman tersebut(Triyawan, 2014, hlm. 51$68)$.

Berdasarkan beberapa pendapat tersebut disimpulkan bahwa Qardh adalah akad pinjam meminjam harta, di mana pinjaman tersebut harus dikembalikan penghutang kepada piutang sesuai nominal awal peminjaman tanpa ada tambahan. Akad Qardh dimaksudkan sebagai bentuk tolong menolong, tanpa ada unsur komersil(Fasiha, 2018, hlm. 23-34). Qardh dalam praktiknya tidak diperbolehkan adanya tambahan (disyaratkan) karena jatuhnya pada Riba, tetapi jika tambahan tersebut diberikan oleh penhutang kepada piutang sebagai rasa terima kasih dan tanpa paksaan, serta bukan yang disyaratkan hal itu diperbolehkan. Mengenai masa pengembalian pinjaman kepada LKS (piutang) ketika sudah jatuh tempo belum juga mampu membayar, maka LKS bisa memperpanjang waktu pengembalian atas permintaan penghutang. Lain halnya ketika nasabah tidak menunjukkan itikad baiknya dalam mengembalikan pinjaman bukan karena tidak mampu mengembalikan, melainkan berniat untuk tidak membayar, maka nasabah dikenakan sanksi. Antisipasi hal tersebut, maka akad Qardh bisa dengan bentuk akad Rahn, di mana jika ketidak mauan penghutang mengembalikan pinjaman, maka LKS bisa memberi sanksi berupa penjualan jamina nasabah (Fatonah, 2019, hlm. 245-270). 
Landasan Qardh sebagai akad kebajikan ada didalam beberapa sumber di bawah ini, antara lain :

a. QS. Al-Baqarah: 245.

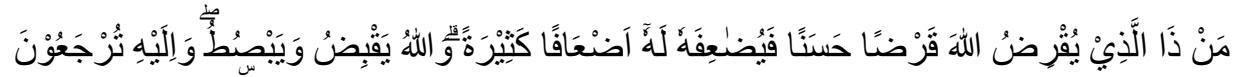
Artinya: "Barang siapa meminjami Allah dengan pinjaman yang baik maka Allah melipat gandakan ganti kepadanya dengan banyak. Allah menahan dan melapangkan (rezeki) dan kepada-Nyalah kamu dikembalikan".(Triyawan, 2014, hlm. 51-68)

b. QS. Al-Hadid: 11

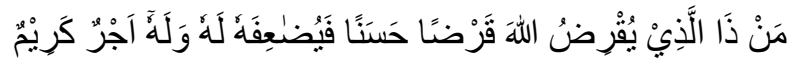

Artinya: "Barang siapa meminjamkan kepada Allah dengan pinjaman yang baik, maka Allah akan mengembalikannya berlipat ganda untuknya, dan baginya pahala yang mulia" (Fasiha, 2018, hlm. 23-34).

Ayat-ayat di atas menjelaskan mengenai keutamaan dan kemuliaan menafkahkan harta di jalan Allah SWT., di mana Allah SWT., akan melipatgandakan pahala bagi pelakunya. Perumpamaan didalam ayat-ayat tersebut di ibaratkan dengan memberikan pinjaman kepada Allah SWT., meskipun Allah SWT., tidak akan membutuhkan pinjaman tersebut. Allah juga akan melapangkan rezeki bagi pelakunya. Begitu muliannya perbuatan tersebut, hingga Allah memberi jaminan yang tidak terukur nilai(Triyawan, 2014, hlm. 51-68). Keutamaan Qardh juga terdapat didalam Hadist Nabi.

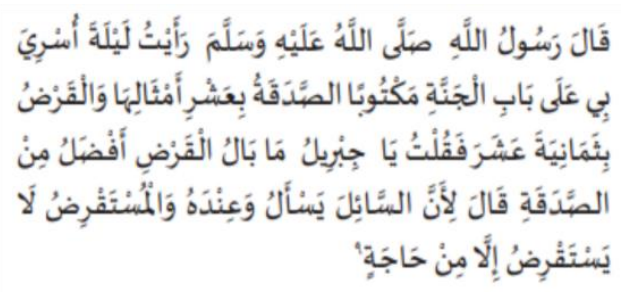

Artinya: Bahwa Rasulullah Saw berkata, "Aku melihat pada waktu malam di israkan, pada pintu surga tertulis: sedekah dibalas sepuluh kali lipat dan qardh delapan belas kali. Aku bertanya, Wahai Jibril, mengapa qardh lebih utama dari sedekah. Ia menjawab, karena peminta-minta sesuatu danaia punya, sedangkan yang meminjam tidak akan meminjam kecuali karena keperluan(HR. Ibnu Majah no. 2421, Kitab al-Ahkam).

Aplikasi Qardh ada beberapa unsur yang harus terpenuhi dalam rukun dan syaratnya, jika tidak bisa terpenuhi maka akad tidak sah dan batal, diantaranya : 

a. Muqridh
: Pemilik harta (Piutang, yang meminjamkan)
b. Mustaridh
: Orang yang berhutang (Penghutang, peminjam)
c. Muqtaridh
: Barang yang di pinjamkan (Obyek)
d. Sighat
: Pernyataan ijab dan Qabul.

Syarat yang harus dipenuhi pelaku Qardh baik Muqridh dan Mustaridh ialah cakap dalam tindakan hukum, sehingga pelaku bisa mengetahui batasan dan tindakan apa yang diperbolehkan. Obyek akad disyaratkan untuk barang yang bisa diukur nilainya dan diketahui jumlahnya, supaya bisa diketahui jelas berapa yang dipinjam dan yang dikembalikan, contohnya uang(Fasiha, 2018, hlm. 23-34).

\section{Rahn}

Rahn merupakan istilah gadai dalam islam dengan bingkai syariah. Secara bahasa Rahn berasal dari kata bahasa Arab yaitu نه yang berarti jaminan, deposito, tetap. Secara istilah Rahn adalah akad utang piutang dengan jaminan barang milik penghutang yang dikembalikan sampai penghutang mampu mengembalikan pinjamannya. Istilah Rahn bisa diketahui dari beberapa pandangan ulama' islam, diantaranya:

a. Menurut Al-Qurtubi

Rahn ialah barang yang ditahan oleh pemberi pinjaman sebagai jaminan dari penghutang, sampai penghutang mampu mengembalikan pinjaman tersebut.

b. Menurut Taqiy al-din Abu Bakar Al-Husaini

Al-rahn ialah al-tsubut yang bermakna sesuatu yang pas. Al-ihtibas yang artinya menahan sesuatu.

c. Ulama Syafi'iyyah

Rahn ialah menjadikan barang yang bisa dijual sebagai jaminan hutang yang memenuhi nilai dari pinjaman tersebut, ketika penghutang tidak mampu mengembalikan pinjamannya(Febrianasari, 2020, hlm. 139-208).

d. Ulama Fiqh

Rahn ialah akad utang piutang dengan menyertakan jaminan sebagai penebus hutang, ketika penghutang belum mampu membayar hutang.

e. Menurut Ahmad Abdul Madjid

Rahn ialah menjadikan barang yang bernilai menurut syara'sebagai jaminan hutang. Sehingga sebagian atau seluruh hutang bisa tertutupi atas barang tersebut (FASIHA, EI, FASIHA, \& EI, 2016, hlm. 121). 
Disimpulkan bahwa Rahn adalah akad pinjam meminjam dengan menjaminkan barang dari penghutang kepada piutang, sebagai jaminan kepercayaan, jika penghutang belum mampu membayar hutangnya maka jaminan bisa dijadikan tebusan yang sepadan dengan nilai pinjaman.

Berdasarkan fatwa mengenai Qardh yang diperbolehkan untuk menolong sesama tanpa unsur Riba dan fatwa mengenai Rahn dengan jaminan. Islam memperbolehkan praktik gadai dengan catatan tanpa adanya unsur Riba dan unsur lain yang diharamkan dalam syariat islam. Para ulama menyepakati bahwa hukum gadai ialah jaiz (boleh atau diperbolehkan), di hukumi sama dengan jual beli karena setiap barang yang diperbolehkan dijual belikan artinya boleh dijadikan objek gadai. Tujuan utama gadai ialah untuk menolong orang yang membutuhkan bantuan, Allah Swt., memerintahkan kepada setiap hamba-Nya untuk saling tolong menolong.

Praktik gadai islam harus sesuai syariat, berikut beberapa sumber dasar hukum gadai islam (Rahn):

a. QS. Al-Baqarah: 283.

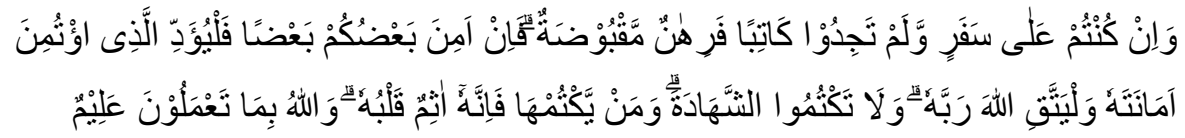

Artinya: "Dan jika kamu dalam perjalanan sedang kamu tidak mendapatkan seorang penulis, maka hendaklah ada barang jaminan yang dipegang. Tetapi, jika sebagian kamu mempercayai sebagian yang lain, hendaklah yang dipercayai itu menunaikan amanatnya (utangnya) dan hendaklah dia bertakwa kepada Allah, Tuhannya. Dan janganlah kamu menyembunyikan kesaksian, karena barang siapa menyembunyikannya, sungguh, hatinya kotor (berdosa). Allah Maha Mengetahui apa yang kamu kerjakan”.

b. QS. Al-Maidah: 2

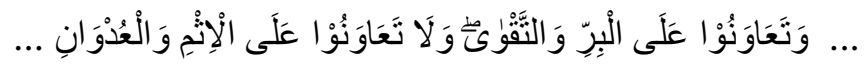

Artinya: “...Dan tolong menolonglah kamu dalam (mengerjakan) kebajikan dan taqwa, dan janganlah tolong menolong dalam berbuat dosa dan pelanggaran...”.

Dari dua ayat tersebut bahwa ketika Anda menghutangi seseorang dan tidak ada seorang saksi dan surat perjanjian hutang, maka bisa menggunakan barang 
jaminan sebagai kepercayaan piutang kepada penghutang atas utang piutang tersebut. Allah Swt., menyukai hamba-Nya yang membantu orang lain dengan tulus tanpa mengharap imbalan dan tidak ada maksud terselubung.

Selain berlandaskan Al-Qur'an gadai juga memperoleh legitimasi hukum dari Hadist Nabi Saw.

HR. Bukhari

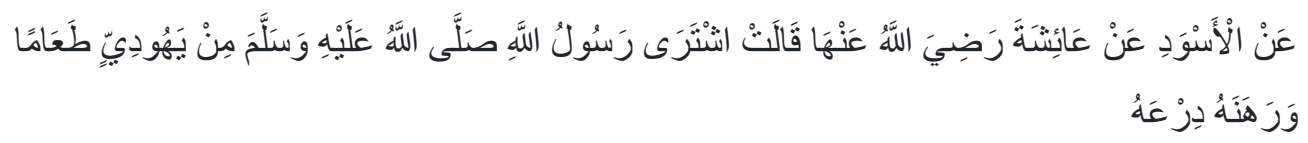

Artinya: "Dari Aswad, dari Aisyah r.a. berkata : Bahwa Rasulullah saw. pernah membeli bahan makanan dari seorang Yahudi secara mengutang kemudian beliau meninggalkan (menggadaikan) baju besi beliau sebagai jaminan utangnya". (HR. Bukhari).

HR. Bukhari

Artinya: "Bahwasanya Nabi saw. menggadaikan baju besinya kalian kepada orang Yahudi yang bernama Abu Syahimi atas pinjamannya sebanyak 30 sha' gandum untuk keluargnya".. (HR. Bukhari).

Bisa diketahui bahwa gadai sudah ada sejak zaman Rasulullah Saw., gadai sebagai bentuk bantuan kepada orang yang kesulitan. Jaminan gadai bentuk kepercayaan dan rasa tanggung jawab dalam utang piutang(FASIHA dkk., 2016, hlm. 124-126).

Rahn memiliki rukun dan syarat yang menjadi aspek penting dalam membangun akad Rahn yang sah dan jalan dalam koridor syari'ah, berikut ini rukun dan syarat Rahn:

a. Ar-Rahin, yaitu pihak penghutang yang menggadaikan barangnya sebagai jaminan.

b. Al-Murtahin, yaitu pihak pemberi pinjaman yang menerima barang gadai penghutang sebagai jaminan gadai.

c. Al-Marhun, yaitu obyek atau barang yang dijadikan jaminan hutang.

d. Al-Marhun Bih, yaitu uang atau utang yang diberikan oleh Murtahin kepada Rahin yang sepadan dengan besaran Marhun.

e. Shighat, yaitu pernyataan ijab dan kabul.

Diantara rukun-rukun di atas ada syarat yang harus terpenuhi. Bagi penghutang dan piutang haruslah orang yang berakal dan mumayyiz, gadai tidak 
boleh dilakukan oleh orang gangguan jiwa, belum baligh, dan anak kecil. Marhun (barang jaminan) harus milik Rahin secara sah di mata hukum, tidak boleh menggadaikan barang milik orang lain tanpa sepengetahuan pemilik, selain itu barang jaminan harus memiliki nilai dan terukur, sepadan dengan hutang, bermanfaat, serta dapat dialih kekuasaan sementara. Marhun bih (utang) jelas jumlahnya, diketahui kedua pihak, dan dikembalikan sesuai kesepakatan. Shighat (pernyataan) ahrus diketahui jelas oleh kedua pihak, disepakati dan dilakukan kedua pihak, serta jika perlu ada hitam di atas putih (Febrianasari, 2020, hlm. 139208).

\section{Fatwa-Fatwa DSN mengenai Qardh dan Rahn}

\section{Qardh}

Berkembangnya trend lembaga keuangan dengan berbagai produk pembiayaan mendorong kemunculan dan perkembangan lembaga keuangan syariah (LKS) dengan berbagai produk pembiayaan yang mampu bersaing dengan pembiayaan konvensional. Tumbuhnya LKS di Indonesia harus berjalan sesuai landasan dasar dan Fatwa-Fatwa DSN MUI sebagai Dewan Syariah yang berwenang dalam mengeluarkan ketentuan-ketentuan, dalam hal ini mengenai Lembaga Keuangan Syariah dan produk-produknya. Fatwa-fatwa yang ada dimaksudkan bahwa sistem pembiayaan dalam LKS sudah memiliki benang merah yang tidak bisa diganggu gugat. Ketentuan Qardh diatur dalam Fatwa DSN-MUI No: 19/DSN-MUI/IV/2001 tentang Qardh. Didalam fatwa ini MUI memberikan beberapa ketentuan dalam praktik Qardh, diantaranya:

a. Pembiayaan Qardh sebagai wujud kegiatan sosial, diharapkan mampu meningkatkan perekonomian masyarakat bawah dan menengah.

b. Al-Qardh adalah pinjaman yang diberikan keoada nasabah yang memerlukan suntikan dana.

c. Nasabah berkewajiban mengembalikan dana al-Qardh sesuai nominal awal pinjaman, pada waktu yang disepakati.

d. Biaya administrasi pengurusan pembiayaan ditanggung oleh nasabah.

e. LKS bisa meminta jaminan kepada nasabah atas permohonan dana yang diajukan, jika dirasa perlu. 
f. Nasabah diperbolehkan memberikan tambahan dana di luar pinjaman pokok, ketika pengembalian pinjaman, selama bukan biaya yang dijanjikan atau disyaratkan dalam akad.

g. Nasabah yang tidak mampu mengembalikan sebagian atau seluruh pinjaman pada waktu yang telah disepakati dan LKS telah memastikan ketidak mampuannya, maka LKS berhak atas dua tindakan, yaitu menambah waktu pengembalian pinjaman, atau menghapus sebagian atau seluruh kewajiban nasabah (Hidayati \& Sarono, 2019, hlm. 931-947).

Jika dicermati ketentuan-ketentuan tersebut sangat meringankan dan memudahkan nasabah dalam memperoleh suntikan dana dari pembiayaan. Namun, bagi nasabah yang tidak taat peraturan LKS, maka akan dijatuhi sanksi, yaitu:

a. Nasabah yang tidak memiliki itikad baik mengembalikan sebagian atau seluruh kewajibannya dan bukan karena faktor ketidak mampuan, maka LKS berhak menjatuhi sanksi kepada nasabah.

b. Sanksi yang diperoleh nasabah sebagaimana butir 1 adalah berupa penjualan aset yang dijaminkan atau aset lain milik nasabah yang sepadan dengan nominal pinjaman.

c. Jika obyek jaminan belum bisa menutupi kewajiban nasabah, maka nasabah tetap memiliki kewajiban untuk memenuhinya(MUI, 2018).

Qardh dalam penerapannya menggunakan landasan syari yang bersumber dari Al-Qur'an dan Hadist. Qardh selain berlandaskan dua sumber utama sebagai sumber hukum islam, landasan Qardh juga dari hasil ijtihad ulama. Ulama menyepakati Qardh atas dasar pemikiran bahwa manusia tidak akan bisa hidup seorang diri, tanpa bantuan orang lain. Kesepakatan ulama tercantum dalam Fatwa DSN-MUI No: 19/DSN/-MUI/IV/2001 tentang Qardh, berisi beberapa dalil penguat atas Fatwa ini, diantaranya:

a. Firman Allah SWT., dalam QS. Al-Baqarah Ayat 282, QS. Al-Baqarah Ayat 280, dan QS. Al-Maidah Ayat 1.

b. Hadist Nabi Saw.

c. Kaidah Fiqh, berbunyi: "Setiap orang yang mendatangkan manfaat bagi yang berpiutang, muqridh adalah Riba (Hidayati \& Sarono, 2019, hlm. 931-947).

Qardh salah satu produk pembiayaan LKS, tetapi lain dari pada produk pembiayaan lain yang memperoleh dana menghimpun dana dari nasabah dan LKS 
memperoleh income bagi hasil. Dana Qardh dihimpun dari masyarakat, tetapi dalam penyalurannya LKS tidak memperoleh income. Berikut sumber dana Qardh:

a. Bagian modal untuk LKS.

b. Keuntungan LKS yang disisihkan.

c. Lembaga atau individu yang menyalurkan infaqnya kepada LKS.

Berdasarkan Fatwa DSN-MUI No: 19/DSN-MUI/IV/2001 tentang Qardh, dijelaskan bahwa Qardh ialah akad pinjaman yang mengharuskan peminjam mengembalikan sesuai nominal, tanpa imbalan. Gerak uatama Qardh dibidang sosial yang bertujuan membantu kesulitan orang lain. Imbalan dalam Qardh diperbolehkan selama hal itu tidak disyaratkan dan suka rela nasabah. Nasabah yang melanggar ketentuan akan dijatuhi sanksi. Akad Qardh bisa mempergunakan jaminan(MUI, 2001). Dana yang digunakan untuk pembiayaan ini diperoleh dari kegiatan sosial, sehingga dalam LKS tergolong dana TBDSP yang tertuang dalam Fatwa DSN-MUI No: 123/DSN-MUI/XI/2018 tentang Penggunaan Dana Yang Tidak Boleh Diakui Sebagai Pendapatan Bagi Lembaga Keuangan Syariah, Lembaga Bisnis Syariah Dan Lembaga Perekonomian Syariah(MUI, 2018).

\section{Rahn}

Ketentuan Rahn sudah diatur dalam Fatwa DSN-MUI No: 25/DSNMUI/III/2002 tentang Rahn(MUI, 2002). Fatwa ini berisi Murtahin memiliki hak untuk menahan Marhun sampai semua Marhun bih milik Rahin dapat dibayar lunas. Meskipun Marhun diserahkan secara fisik kepada Murtahin, tetapi Marhun tetap hak milik Rahin. Marhun tidak boleh dimanfaatkan oleh Murtahin, tanpa izin dan sepengetahuan Rahin. Jika Rahin mengizinkan, Murtahin diperbolehkan memanfaatkan Marhun dengan semestinya, tidak menambah dan mengurangi nilai dan manfaatnya, serta biaya perawatan ditanggung oleh Murtahin atas pemanfaatan tersebut. Tetapi jika Murtahin tidak memanfaatkan Marhun tersebut, maka ia tidak memiliki kewajiban untuk mengeluarkan biaya perawatan dan itu tetap kewajiban Rahin sebagai pemilik Marhun.

Biaya perawatan atas Marhun tidak boleh ditentukan dengan menyesuaikan besaran jumlah pinjaman. Ketika dalam pelunasan pinjaman sampai jatuh tempo Rahin belum mampu mengembalikan pinjamannya dan ketika sudah diperpanjang waktunya juga belum mampu mengembalikan pinjaman(Triyawan, 2014, hlm. 5168). Marhun sebagai jaminan boleh dijual oleh LKS. Jika nasabah sudah siberi 
peringatan oleh LKS untuk melunasi pinjamannya hingga waktu jatuh tempo, tetapi nasabah belum mampu melunasinya, maka Marhun diperbolehkan dijual oleh LKS melalui lelang syariah. Hasil penjualan Marhun digunakan sebagai pelunas pinjaman, biaya pemeliharaan dan penyimpanan Marhun selama ditangan Rahin, serta biaya untuk penjualan Marhun(MUI, 2001). Biaya penyimpanan barang jaminan ditanggung oleh penghutang dan besaran biaya ditentukan dari pengeluaran yang sebenarnya dalam pemeliharaan jaminan (Manahaar, 2019, hlm. 98-106).

Fatwa ini dibuat guna mengatur jalannya Rahn, tetapi tidak menutup kemungkinan dalam praktiknya akan ditemui berbagai kondisi yang tidak sesuai, sebut saja ketika salah satu pihak tidak melaksanakan kewajibannya dan terjadi perselisihan diantara kedua pihak. Langkah pertama yang bisa dilakukan dengan mendudukkan kedua pihak dan bermusyawarah atas perselisihan tersebut, tetap jika musyawarah belum bisa mengatasi perselisihan, maka bisa melalui Badan Arbitrase Syariah(Triyawan, 2014, hlm. 51-68).

\section{Pertaturan Perundang-Undangan Qardh dan Rahn, serta Peraturan Pendukungnya}

\section{Qardh}

Qardh sebagai pinjaman kepada nasabah yang dapat diminta dan harus dikembalikan, tanpa imbalan tidak hanya berjalan dengan peraturan didalam Fatwa, tetapi juga berjalan dengan peraturan perundang-undangan. Menurut Pasal 19 huruf E UU No. 2 Tahun 2008, Qardh adalah perjanjian pinjaman dana oleh nasabah dengan syarat nasabah berkewajiban mengembalikan dana yang dipinjam pada waktu yang telah disepakati (Ash-Shiddiqy, 2018, hlm. 102-110). Sedangkan menurut Pasal 1 angka 1 dalam Peraturan Bank Indonesia No.7/46/PBI/2005 tentang Akad Penghimpunan dan Penyaluran Dana Bagi Bank yang Melaksanakan Kegiatan Usaha Berdasarkan Prinsip Syariah, Qardh adalah peminjaman dana tanpa imbalan, peminjam hanya berkewajiban mengembalikan pinjaman pokok secara lunas sekaligus atau dengan angsuran(Hidayati \& Sarono, 2019, hlm. 931947). Qardh sudah diakui sebagai pembiayaan yang sah secara hukum yuridis, yang dinyatakan dalam Pasal 1 angka 5 bahwa pembiayaan adalah penyediaan dana yang disamakan dengan hal itu (5 produk produk pembiayaan), diantaranya: 
a. Transaksi bagi hasil dalam Mudharabah dan Musyarakah.

b. Transaksi sewa beli dalam Ijarah.

c. Transaksi jual beli Murabahah, Salam, dan Istishna'.

d. Transaksi pinjam meminjam dalam Qardh.

e. Transaksi sewa jasa dalam Ijarah(Abdillah, 2021, hlm. 42-51).

Pada pasal 3 Peraturan Bank Indonesia No: 9/19/PBI/2007 tentang Pelaksanaan Prinsip Syariah dalam Kegiatan Penghimpunan Dana dan Penyaluran Dana, serta Pelayanan Jasa Bank Syariah, Qardh adalah perjanjian pinjaman dan tanpa imbalan, di mana peminjam berkewajiban mengembalikan pinjaman secara tunai lunas atau angsuran, dengan tempo waktu tertentu. Sedangkan pada Pasal 19 ayat 1 huruf e Undang-Undang No. 21 Tahun 2008 tentang Perbankan Syariah, Qardh adalah pinjaman dana oleh nasabah yang wajib dikembalikan pada batas waktu yang disepakati kedua pihak (Hidayati \& Sarono, 2019, hlm. 931-947). Berdasarkan beberapa undang-undang yang sudah tercantum bahwa undangundang secara hukum yuridis ini mengenai pengakuan dan keabsahan produk pembiyaan Qardh sebagai pembiayaan yang boleh dan sah di mata hukum negara, sedangkan aturan pelaksanaan terdapat dalam Fatwa DSN-MUI No: 19/DSNMUI/IV/2001 tentang Qardh.

Diterbitkannya peraturan hukum yuridis mengenai akad Qardh yang tercantum dalam Undang-Undang No 21 Tahun 2008 tentang Perbankan Syariah, memiliki beberapa dasar pijakan pada peraturan undang-undang sebelumnya, diantaranya:
a. Pasal 20 dan Pasal 33 UUD RI Tahun 1945
b. Undang-Undang No. 7 Tahun 1992 Tentang Perbankan
c. Undang-Undang No. 23 Tahun 1999 Tentang Bank Indonesia
d. Undang-Undang No. 24 Tahun 2004 Tentang Lembaga Penjamin Simpanan
e. Undang-Undang No. 40 Tahun 2007 Tentang Perseroan Terbatas.
Pada Undang-Undang No. 21 Tahun 2008 Tentang Perbankan Syariah, Pasal 35 Ayat 1 bahwa Bank Syariah dan Unit Usaha Syariah lainnya dalam operasional pembiayaan wajib mengimplementasikan prinsip kehati-hatian. Tujuannya menjaga berkembangnya usaha dalam LKS, sehingga segala bentuk akad dalam LKS harus menerapkan prinsip ini begitu juga akad Qardh dan Rahn. 
Pijakan Dasar Pasal 35 Ayat 1 Tentang Perbankan Syariah, di mana LKS harus mengedepankan prinsip kehati-hatian dalam Qardh, diantaranya:

a. Pasal 1 Angka 25 Huruf d: Pembiayaan adalah penyediaan dana berupa perjanjian pinjam meminjam dalam bentuk akad Qardh.

b. Pasal 19 Ayat 1 Huruf e: Kegiatan usaha Bank Umum Syariah, yaitu mendistribusikan pembiayaan melalui akad Qardh atau bentuk akad lain yang tidak bertentangan prinsip syariah.

c. Pasal 19 Ayat 2 Huruf e: Kegiatan usaha UUS ${ }^{2}$, yaitu mendistribusikan pembiayaan melalui akad Qardh atau bentuk akad lain yang tidak bertentangan prinsip syariah.

d. Pasal 21 Huruf b angka 3: Kegiatan usaha Bank Pembiayaan Rakyat adalah mendistribusikan dana kepada masyarakat melalui pembiayaan berdasarkan akad Qardh(Nugroho, 2020, hlm. 33-46).

\section{Rahn}

Qardh sebagai pinjaman bisa di aplikasikan dalam sistem gadai syariah. Sama halnya Qardh, Rahn juga memiliki hukum yuridis. Berdasarkan Pasal 1 Ayat 26 Undang-Undang Nomor 21 Tahun 2008 Tentang Perbankan Syariah, Rahn (agunan) adalah jaminan yang berupa benda bergerak atau tidak, yang diserahkan oleh peminjam kepada LKS untuk menjamin pemenuhan kewajiban nasabah atas fasilitas yang diperoleh dari $\operatorname{LKS}(\mathrm{KN}, 2019$, hlm. 438-452). OJK mengeluarkan peraturan Nomor: 31/POJK.05.2016 Tentang Usaha Pergadaian, yang menjadi landasan hukum layanan usaha pegadaian. Terbitnya peraturan ini, berawal dari menjamurnya gadai online yang belum jelas legalitasnya, sehingga peraturan ini untuk memberikan kepastian dan perlindungan hukum bagi pelaku pegadaian $(\mathrm{KN}$, 2019, hlm. 438-452). Menurut Pasal 20 Ayat 14 KHES, Rahn atau gadai syariah adalah penguasaan barang milik penghutang oleh piutang (orang yang meminjami) sebagai jaminan. Peraturan gadai syariah dalam undang-undang terpusat pada Peraturan Pemerintah Nomor 103 Tahun 2000 (Luluk \& Mohammad, 2018, hlm. 27-43). Keberadaan Rahn dimaksudkan untuk menghindarkan praktik riba, sebut saja PP 10 tanggal 1 April 1990 sebagai tonggak kebangkitan Pegadaian sebagai misi yang harus ditegakkan oleh pegadaian untuk mencegah Riba. Sampai terbit PP103 Tahun 2002 sebagai landasan kegiatan usaha Perum Pegadaian hingga sekarang, misi mencegah Riba tetap diutamakan (Surepno, 2018, hlm. 174-186). 
Usaha pegadaian dimaksudkan bisa mendorong keuangan dan usaha kecil dan menengah, di mana pegadaian akan memberikan akses kemudahan terhadap pinjaman, dalam pelaksanaan gadai perlu adanya peraturan guna memberikan perlindungan hukum bagi pelaku gadai, sehingga perlu adanya landasan hukum bagi Otoritas Jasa Keuangan dalam mengawasi jalannya Pegadaian. Pegadaian diawasi langsung oleh OJK, sebagai lembaga yang berwenang dalam mengawasi lembaga-lembaga keuangan lainnya(OJK, 2016). Peraturan Pegadaian tercantum dalam Peraturan Pemerintah Republik Indonesia Nomor 178 Tahun 1961 Tentang Pendirian Perusahaan Negara Pegadaian. Aturan pendirian hingga operasionalnya tercantum dalam peraturan tersebut (Peraturan Pemerintah Republik Indonesia, 1961).

\section{Skema Qardh dan Rahn}

\section{Qardh}

Pengajuan pembiayaan Qardh harus memenuhi beberapa ketentuan dan alur pengajuan, jika satu prosedur terlewatkan bisa saja pengajuan pembiayaan tidak disetujui LKS. Berikut skema pengajuan Qardh:

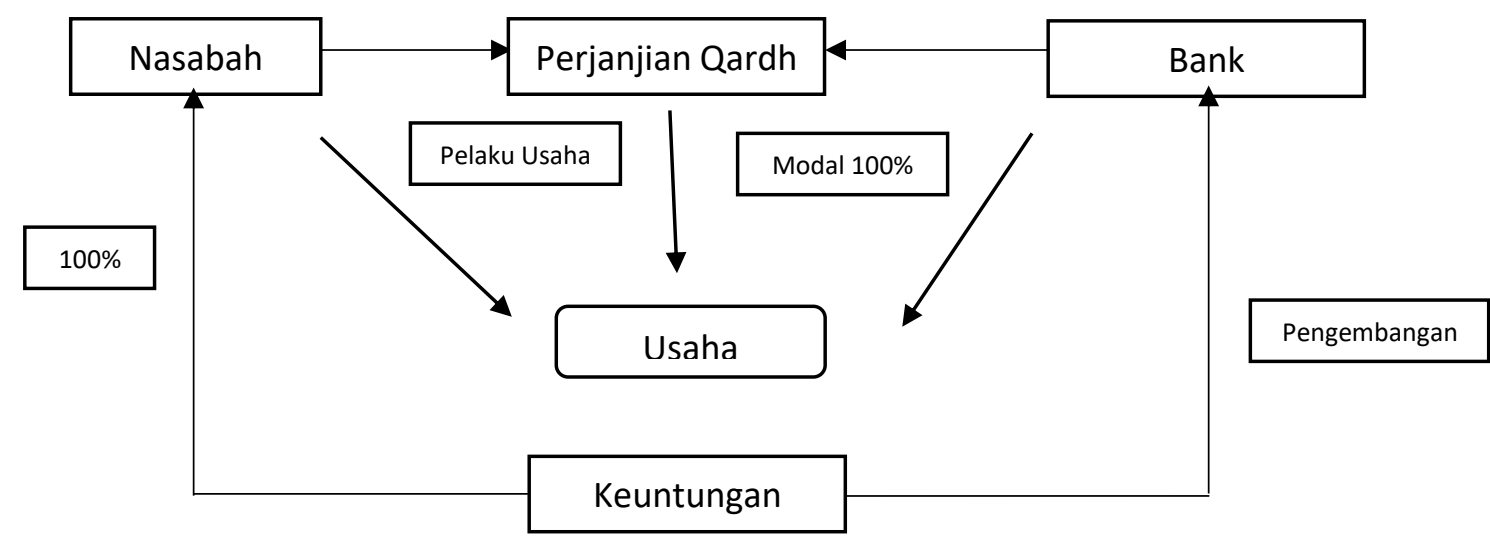

Skema tersebut menggambarkan bahwa peran LKS hanya sebagai penyalur dana yang diperoleh dari infaq, zakat, dan shadaqah. Kemudian dana tersebut disalurkan kepada masyarakat berupa pembiayaan Qardh, yang harus dikembalikan sesuai nominal pinjaman, tanpa imbalan. LKS tidak boleh meminta bagi hasil atas pinjaman ini karena motif pinjaman ini tujuan sosial (Fasiha, 2018, hlm. 23-34). Tetapi LKS diperbolehkan meminta pinjaman pokok ketika sudah jatuh tempo nasabah belum juga mengembalikan dan tidak itikad baik, maka LKS 
diperbolehkan menjual barang jaminan atau menyita harta benda sebagai pengganti pinjaman(MUI, 2001).

\section{Rahn}

Sama halnya Qardh, akad Rahn juga memiliki alur pengajuan supaya semua syarat dan ketentuan pengajuan lebih sistematis dan tidak terlewatkan satu pun. Berikut skema Rahn:

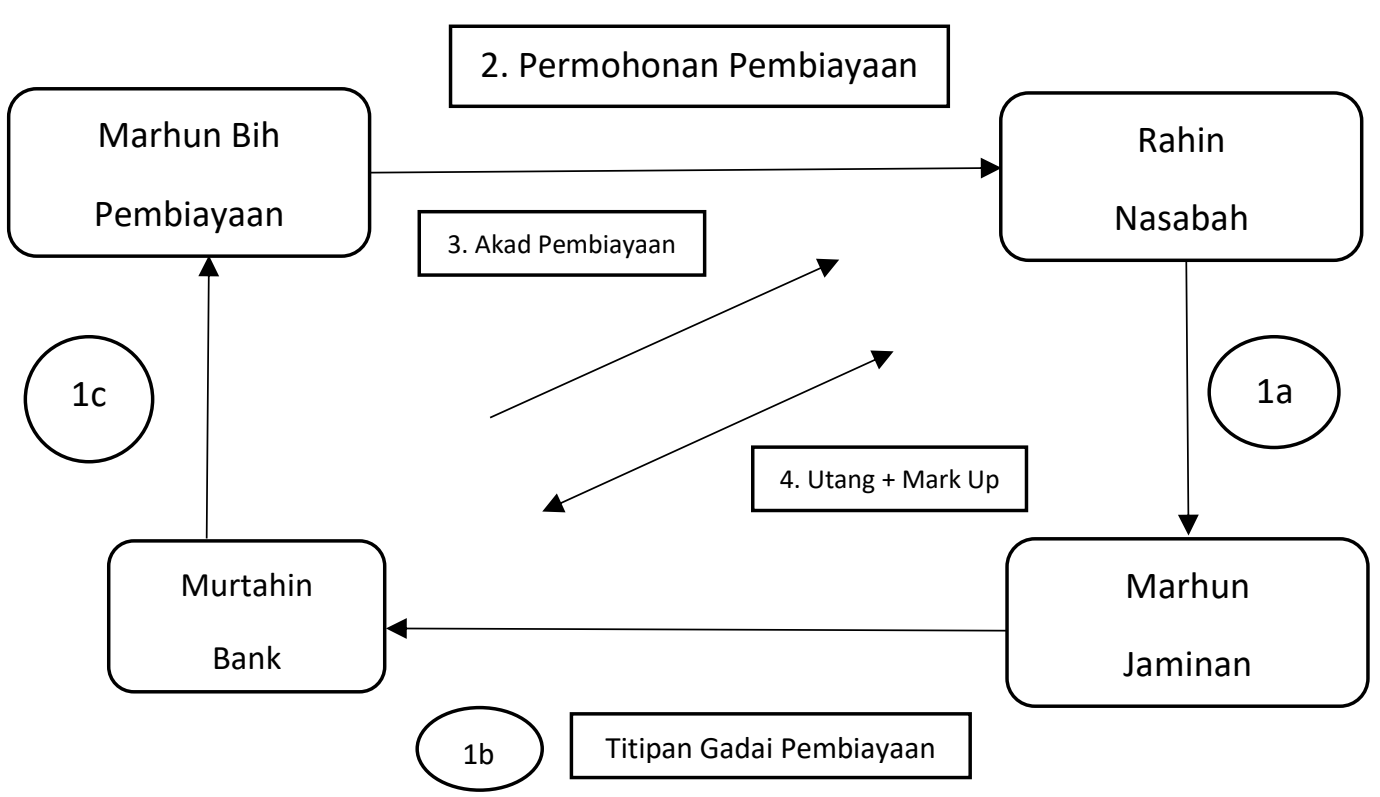

LKS sebagai penyalur dana akan menghimpun dana dari masyarakat dan menyalurkan kepada masyarakat kembali dalam bentuk pembiayaan. Skema di atas menggambarkan bahwa Rahin yang akan mengajukan permohonan pinjaman Rahn kepada LKS harus memiliki barang jaminan untuk digadaikan, sebagai jaminan Marhun Bih. Jika syarat satu a, b, dan c sudah dipenuhi, Rahin dapat mengajukan permohonan pembiayaan. Kemudian jika permohonan nasabah dikabulkan LKS, maka antara LKS dan nasabah akan melakukan akad pembiayaan. Setelah itu dana yang diajukan nasabah akan diberikan oleh LKS, yang disertai penyerahan barang jaminan (Lubaba, 2020, hlm. 49-58).

\section{METODE PENELITIAN}

Penelitian ini menggunakan studi literatur dengan mencari, mengumpulkan, serta mengolah data - data yang relevan. Studi kasus yang diperoleh bersumber dari kasus berita yang relevan. Referensi mengenai teori didapat melalui studi literatur yang digunakan untuk menganalisis studi kasus dan data. Jenis data yang digunakan adalah 
data sekunder, di mana sumbernya dari skripsi, jurnal, buku, serta website yang terkait. Metode yang digunakan dalam penelitian ini adalah analisis deskriptif, dengan menganalisis dan membedah data yang didapatkan, serta memberikan penjelasan antara kasus dengan teori.

\section{HASIL DAN PEMBAHASAN}

\section{Studi Kasus Pinjaman Usaha dalam Qardh dan Rahn Dalam Lembaga Keuangan Syariah}

Pengajuan pinjaman permohonan modal bukan hal asing lagi, apalagi dalam dunia usaha. Pinjaman usaha dilakukan baik usaha kecil atau menengah. Pengajuan pinjaman usaha di latar belakangi berbagai motif, mulai dari untuk pengembangan usaha, menyelamatkan usaha dari jurang kebangkrutan, hingga pinjaman usaha untuk memulai bisnis. Tawaran pinjaman untuk usaha sekarang ini marak sekali, mereka tidak hanya menyebarkan brosur tetapi mereka juga mendatangi pintu ke pintu untuk menawarkan pinjaman usaha. Penawaran pinjaman pernah saya alami sendiri, mereka menggunakan strategi bunga pinjaman yang rendah. Pinjaman kini juga menggunakan metode online, mereka tidak perlu mendatangi nasabah, cukup dengan iklan yang menarik di sosial media. Sayangnya pinjaman yang ada sekarang tidak semua lembaga sudah mengantongi izin dan belum terjamin legalitasnya.

Sehingga masih saja ditemui penipuan pinjaman, misalnya saja kasus terbaru seorang petani buta huruf di Banyuwangi menjadi korban penipuan pinjaman dengan modus pinjaman Kredit Usaha di bank, awalnya petani ini meminjam modal sejumlah 5 juta rupiah, tetapi lambat laun tanpa sepengetahuannya utang tersebut berlipat ganda menjadi 25 juta(Fanani, 2021). Kasus tersebut menunjukkan bahwa masih rendahnya jaminan keamanan masyarakat dalam meminjam modal usaha, serta perlunya pengakuan legalitas dalam usaha. Oleh akrena itu masyarakat sangat membutuhkan lembaga yang menjamin hak dan keamanan mereka dalam pinjaman. Mayoritas masyarakat akan lari ke lembaga konvensional, baik itu Bank atau Lembaga Keuangan lainnya. Lembaga konvensional lebih dahulu dikenal masyarakat, padahal didalamnya terdapat praktik bunga, di mana dalam islam bunga di hukumi sama dengan Riba yang hukumnya haram.

Dirasa masyarakat memerlukan lembaga berbasis syariah, maka munculah Lembaga Keuangan Syariah yang tercantum dalam Peraturan Menteri Sosial Republik 
Indonesia Nomor 184 Tahun 2011 Tentang Lembaga Kesejahteraan Sosial Dengan Rahmat Tuhan Yang Maha Esa Menteri Sosial Republik Indonesia.(Indonesia, 2011) Jaminan keamanan dalam LKS diwujudkan dalam berbagi produk pembiayaan, seperti pada akad Qardh dan Rahn. Tidak dapat di pungkiri bahwa kedua pembiayaan ini sering dipilih pengusaha karena prosedur pengajuan yang cukup mudah. Pada akad Qardh nasabah ketentuan utama disamping ketentuan administrasi, nasabah cukup mengembalikan pinjaman pokok tanpa imbalan. Pada akad Qardh bisa disisipkan praktik Rahn. Qardh bisa menggunakan jaminan barang jika dirasa perlu, sehingga hal itu sekilas seperti praktik Rahn(MUI, 2001).

Perbedaannya hanya pada sumber dana yang digunakan untuk pembiayaan. Qardh berasal dari dana sosial, sedangkan Rahn dari dana produktif. Pembiayaan Qardh dan Rahn memiliki hukum yuridis yang akan memberikan perlindungan hukum bagi nasabah, yang diatur dalam Undang-Undang No. 21 Tahun 2008 tentang Perbankan Syariah(Nugroho, 2020, hlm. 33-46). Selain peraturan secara hukum yuridis kedua pembiayaan tersebut juga memiliki hukum syariah berupa fatwa. Fatwa DSN-MUI No: 19/DSN-MUI/IV/2001 tentang Al-Qardh(MUI, 2001). Fatwa DSN-MUI No. 25/DSNMUI/III/2002 tentang Rahn(MUI, 2002). Penyebab utama maraknya penipuan berkedok pinjaman ialah kebutuhan manusia yang semakin bertambah, namun penghasilan mereka tidak mengalami kenaikan, yang membuat mereka harus tetap bisa memenuhi kebutuhan hidup.

\section{Analisis Qardh dan Rahn}

Maraknya penipuan dan keraguan legalitas atas tempat pinjaman, sekarang masyarakat lebih kritis dan teliti dalam memilih lembaga peminjaman. Banyak dari masyarakat memilih LKS sebagai tempat peminjaman, contohnya saja BMT. Qardh dan Rahn adalah praktik pinjaman yang sering digunakan untuk memperoleh pinjaman modal. Pengajuan yang mudah, di mana nasabah cukup mendatangi LKS dengan beberapa syarat yang diperlukan, kemudian LKS akan mengecek validitas data dan cek beberapa data yang dibutuhkan, dengan berbagai pertimbangan dan kesepakatan, pinjaman tersebut bisa di Acc. Bentuk pinjaman Qardh yang sering digunakan ialah akad Rahn karena dengan jaminan akan memberi keamanan baik untuk nasabah atau LKS. Dalan Qardh boleh diadakan jaminan jika diperlukan. 
Jaminan dalam pembiayaan dimaksudkan sebagai talangan atas pinjaman, jika suatu hari pinjaman nasabah sudah jatuh tempo tetapi nasabah belum mampu mengembalikan dan tidak akan bisa mengembalikan, maka pinjaman nasabah akan dilunasi dengan hasil penjualan atas jaminan. Jaminan akan dilelang oleh LKS, hasil penjualan atas jaminan selain untuk melunasi hutang, juga untuk mengganti biaya pemeliharaan, perawatan, dan biaya penyimpanan jaminan. Pembiayaan Qardh, nasabah harus mengembalikan pinjaman pokok tanpa imbalan atau tambahan yang disyaratkan, jika nasabah memberikan tambahan tanpa disyaratkan dan tidak disebutkan dalam perjanjian maka hal itu diperbolehkan. Sedangkan Rahn, pinjaman dengan mengembalikan pokok pinjaman beserta pendapatan bagi hasil karena akad Rahn untuk bagi hasil atas usaha yang dijalankan nasabah, maka LKS berhak memperoleh bagi hasil.

Bagi hasil yang dimaksudkan bukanlah Riba karena di ibaratkan LKS menginvestasikan dananya kepada nasabah dan nasabah yang akan mengembangkan dana tersebut. Jangka waktu pengembalian Qardh dan Rahn ditentukan dan disepakati kedua pihak. Ada catatan penting mengenai akad Qardh, jika dalam pembiayaan ini nasabah tidak mengembalikan pinjaman secara utuh, bukan karena ketidak mampuan membayar melainkan gerak geriknya menunjukkan ketidak mauan untuk mengembalikan pinjaman, maka LKS berhak memberikan sanksi. Sanksi yang dikenakan berupa penjualan barang jaminan, tetapi jika tidak menjaminkan barang, maka LKS diperbolehkan menyita barang milik nasabah yang setara nilainya dengan pinjaman nasabah. Penyitaan barang nasabah tentunya ada prosedur dan sebelumnya

juga ada surat peringatan jatuh tempo pinjaman. Dalam akad Qardh dan Rahn harus memenuhi rukun dan syarat yang sudah ditentukan karena terpenuhinya dua hal tersebut menjadi kunci sah tidaknya akad. Disamping itu alur skema masing-masing akad harus di lakukan secara runtut karena berkesinambungan dengan rukun dan syarat. Kunci sah tidaknya akad ini ada pada terpenuhinya ruku, syarat, dan sistem yang dipergunakan, serta tetap menegakkan syariat islam.

\section{KESIMPULAN}

Berdasarkan hasil penelitian, pembiayaan yang rekomendasi untuk pinjaman usaha adalah Qardh dan Rahn, keduanya memiliki resiko yang relatif rendah dan proses peminjaman yang cukup mudah. Qardh adalah pinjaman yang harus dikembalikan 
sesuai nilai yang dipinjam, pengembalian tanpa imbalan. Rahn adalah pinjaman yang menyertakan jaminan sebagai bentuk kepercayaan atas pinjaman. Rahn harus dikembalikan sesuai nominal awal dan jika akadnya didasarkan bagi hasil, maka nasabah harus memberikan bagi hasil kepada LKS. Qardh dan Rahn, salah satu produk LKS yang menghindarkan praktik Riba didalamnya. Qardh, diperbolehkan karena memiliki misi sosial dalam membantu orang yang membutuhkan dana dalam mengembangkan dan mengelola usaha. Sedangkan pinjaman dengan jaminan, diperbolehkan di mana pinjaman untuk membantu orang dalam memperoleh modal usaha dan jaminan sebagai wujud tanggung jawab peminjam dan simbol kepercayaan LKS kepada nasabah atau peminjam. Qardh dan Rahn dalam LKS sudah diakui keabsahannya yang tertuang dalam Undang-Undang Nomor 21 Tahun 2008 Tentang Perbankan Syariah.

Selain diakui sebagai pembiayaan yang sah di mata hukum, kedua pembiayaan tersebut juga diperbolehkan secara syar'i yang tertuang dalam landasan LKS, yaitu AlQur'an dan Hadist, serta ijtihad ulama. Pada masing-masing pembiayaan memiliki rukun masing-masing, rukun Qardh meliputi Muqridh (piutang), Mustaridh (penghutang), Muqtaridh (Obyek) dan Sighat (Pernyataan ijab dan Qabul. Rukun dan syarat Rahn hampir sama dengan Qardh, hanya saja istilah pada rukun yang berbeda. Pada Rahn rukunnya meliputi, Ar-Rahin (penghutang), Al-Murtahin (piutang), AlMarhun (objek), Al-Marhun Bih (utang) dan Shighat (pernyataan) Semua rukun tersebut memiliki syarat masing-masing yang harus dipenuhi. Jika salah satu rukun atau syarat tidak terpenuhi, maka akad dianggap batal dan tidak sah bila di lanjutkan. Banyak pinjaman dengan penipuan, LKS hadir dengan legalitas resmi yang mampu mengayomi nasabah, sehingga nasabah memperoleh perlindungan pinjaman. Dengan beralih pada pembiayaan sistem syariah akan menghindarkan praktik Riba, sehingga usaha yang dijalan semakin lancar dan berkah.

Berdasarkan pembahasan dan kesimpulan penelitian ini, maka penulis rekomendasi beberapa hal berikut ini:

1. Bagi peneliti selanjutnya hendaknya diadakan penelitian lebih lanjut dan mendalam mengenai Qardh dan Rahn, baik di lingkungan LKS atau Perbankan Syariah. Tentunya yang sesuai dengan perkembangan pembiayaan, guna memantau perkembangan akad Qardh dan Rahn dalam pinjaman usaha. 
2. Maraknya penipuan pinjaman dan dalam rangka menghindari praktik Riba dalam pinjaman, maka pembiayaan pada produk LKS adalah pilihan tepat. Nasabah dipermudah dalam pembiayaan Qardh dan Rahn. Legalitas yang terjamin dan perlindungan nasabah diutamakan, sehingga meminimalisir kerugian yang berlipat.

3. Bagi lembaga keuangan syariah hendaknya LKS lebih gencar lagi dalam mensosialisasikan keberadaan LKS dan berbagai produk pembiayaannya. Sehingga masyarakat akan mengenal LKS dan berbagai produk pembiayaannya. Pendekatan secara personal dan verbal ini akan menambah keyakinan masyarakat terhadap legalitas dan keabsahan LKS sebagai Lembaga Keuangan yang sah dan dilindungi hukum.

\section{REFERENSI}

Abdillah, Y. K. (2021). Pelaksanaan Akad Pembiayaan Qardh di Koperasi Baiturrahim Syariah Kopo Sayati Bandung. Ecopreneur: Jurnal Program Studi Ekonomi Syariah, 2(1), 42-51.

Afdhila, G. K. (2013). Analisis Implementasi Pembiayaan Ar-Rahn (Gadai Syariah) Pada Kantor Pegadaian Syariah Cabang Landungsari Malang. Jurnal Ilmiah Mahasiswa FEB, 2(2).

Ash-Shiddiqy, M. (2018). Analisis akad pembiayaan qardh dan upaya pengembalian pinjaman di lembaga keuangan mikro syariah. Proceeding of Conference on Islamic Management, Accounting, and Economics, 1(1), 101-110.

Fanani, A. (2021). Ditipu dengan Modus Pinjaman Bank, Petani Banyuwangi lapor Polisi. Detik.com.

Fasiha. (2018). Akad Qardh Dalam Lembaga Keuangan Syariah. Al-Amwal: Journal of Islamic Economic Law., 3(1), 23-34.

FASIHA, S., EI, M., FASIHA, S., \& EI, M. (2016). Islamic Finance (Konsep dan Aplikasi dalam Lembaga Keuangan Syariah). Sulawesi Selatan: Laskar Perubahan.

Fatonah, S. (2019). Analisis Implementasi Rahn, Qardh Dan Ijarah Pada Transaksi Gadai Emas Syariah PT. Bank Syariah Mandiri Kantor Cabang Serang. Banque Syar'i: Jurnal llmiah Perbankan Syariah, 3(2), 245-270.

Febrianasari, S. N. (2020). Hukum Ekonomi Islam Dalam Akad Ijarah Dan Rahn (Islamic Economic Law In The Ijarah And Rahn Contracts). Qawãnün: Journal of Economic Syaria Law, 4(2), 193-208.

Hidayati, N., \& Sarono, A. (2019). PELAKSANAAN AKAD QARDH SEBAGAI AKAD TABBARU. NOTARIUS, 12(2), 931-947.

Indonesia, P. M. S. R. Peraturan Menteri Sosial Republik Indonesia Nomor 184 Tahun 2011 Tentang Lembaga Kesejahteraan Sosial Dengan Rahmat Tuhan Yang Maha Esa Menteri Sosial Republik Indonesia. , (2011).

KN, M. U. (2019). Analisis Kewenangan Gadai Syariah Menurut Peraturan Otiritas Jasa Keuangan Nomor 31/Pojk. 05/2016 Tentang Usaha Pegadaian. Az Zarqa': Jurnal Hukum Bisnis Islam, 11(2). 
Lubaba, A. (2020). IMPLEMENTASI AKAD RAHN DALAM PERSPEKTIF EKONOMI ISLAM. Ecopreneur: Jurnal Program Studi Ekonomi Syariah, 1(2), 49-58.

Luluk, W. R., \& Mohammad, G. (2018). Aplikasi Akad Rahn Pada Pegadaian Syariah. Jurnal Masharif al-Syariah: Jurnal Ekonomi dan Perbankan Syariah, 3(2), 27.

Manahaar, P. (2019). Implementasi Gadai Syariah (Rahn) Untuk Menunjang Perekonomian Masyarakat di Indonesia. Dialogia Iuridica: Jurnal Hukum Bisnis dan Investasi, 10(2), 97-104.

MUI. Fatwa DSN-MUI No: 19/DSN-MUI/IV/2001 tentang Al-Qardh. , (2001).

MUI. Fatwa DSN-MUI No. 25/DSN-MUI/III/2002 tentang Rahn. , (2002). https://dsnmui.or.id/kategori/fatwa/.

MUI. Fatwa DSN-MUI No.1 tahun 2004 tentang Bunga. , (2004).

MUI. Fatwa DSN-MUI No: 123/DSN-MUI/XI/2018 tentang Penggunaan Dana Yang Tidak Boleh Diakui Sebagai Pendapatan Bagi Lembaga Keuangan Syariah, Lembaga Bisnis Syariah Dan Lembaga Perekonomian Syariah. , (2018).

Nugroho, H. B. (2020). PRINSIP KEHATI-HATIAN PADA AKAD QARDH DALAM PERBANKAN SYARIAH DI INDONESIA. Al-Amwal: Journal of Islamic Economic Law, 5(1), 32-46.

OJK. Peratauran Otoritas Jasa Keuangan Nomor 31/POJK.05/2016 Tentang Usaha Pergadaian. , Pub. L. No. 31/POJK.05/2016, 1 (2016). Indonesia: https://www.ojk.go.id/id/regulasi/otoritas-jasa-keuangan/peraturanojk/Pages/POJK-usaha-pergadaian-.aspx.

Oktavia, N. W. (2020). Manajemen Risiko Pembiayaan pada Akad Al-Qardh di BMT Assyafi'iyah. IAIN Metro.

Peraturan Pemerintah Republik Indonesia. Peraturan Pemerintah Republik Indonesia Nomor 178 Tahun 1961 Tentang Pendirian Perusahaan Negara Pegadaian Presiden Republik Indonesia. , (1961).

Surepno, S. (2018). Studi Implementasi Akad Rahn (Gadai Syariah) Pada Lembaga Keuangan Syariah. TAWAZUN: Journal of Sharia Economic Law, 1(2), 174186.

Susilo, E. (2017). Shariah Compliance Akad Rahn Lembaga Keuangan Mikro Syariah (Studi Kasus BMT Mitra Muamalah Jepara). IQTISHADIA: Jurnal Ekonomi dan Perbankan Syariah, 4(1), 120-136.

Triyawan, A. (2014). Konsep Qard Dan Rahnmenurut Fiqhalmadzhahib. Ijtihad: Jurnal Hukum dan Ekonomi Islam, 8(1), 51-68. 